\title{
Effect of selected rumen fauna on the digestion of starch and outflow of $\alpha$-glucose polymers from the reticulo-rumen of sheep
}

\author{
G. Bełżecki and T. Michałowski ${ }^{1}$ \\ The Kielanowski Institute of Animal Physiology and Nutrition, Polish Academy of Sciences \\ 05-110 Jabłonna, Poland
}

\begin{abstract}
The role of rumen ciliates in starch digestion is not well known. The objective of this study was to examine the influence of the ciliates Eudiplodinium maggii and Entodinium caudatum on the turnover of dietary starch in the rumen. It was found that ciliates significantly increased the contents of $\alpha$-D-glucose polymers in the rumen and their amount passing to the omasum $(\mathrm{P}<0.05)$. Competition among the ciliate species for starch was also observed. It is concluded that the effect of ciliates on the metabolism of starch consists of a restrictive influence on the bacterial fermentation of this polysaccharide in the rumen.
\end{abstract}

KEY WORDS: starch, digestion, $\alpha$-glucose polymers, rumen ciliates

\section{INTRODUCTION}

Farm ruminants are often fed starch-rich diets (Lyle et al., 1981; Whitelaw et al., 1984). This dietary polysaccharide is digested and fermented by bacteria, fungi and protozoa inhabiting the rumen. The role of protozoa in starch metabolism is controversial (Veira et al., 1983; Rowe et al., 1985; Mendoza et al., 1993). It is well known, however, that all of the examined species exhibit amylolytic activity (Williams and Coleman, 1992). Thus, the objective of this study was to examine the influence of ciliate fauna established in ciliate-free sheep on the contents of $\alpha$-D-glucose polymers in the rumen and their quantity passing to the omasum.

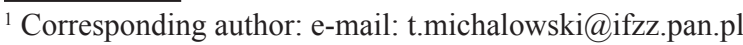




\section{MATERIAL AND METHODS}

Two Polish Merino rams (No 33 and 35) fitted with large rumen fistulae were kept in separate pens and fed meadow hay $(750 \mathrm{~g})$ and ground barley $(130 \mathrm{~g})$ every $12 \mathrm{~h}$. Water was available ad libitum.The study comprised three experimental periods. Period 1, ciliate-free animals; period 2, rams refaunated with Eudiplodinium maggii; period 3, rams refaunated with Eudiplodinium maggii and Entodinium caudatum. The animals were defaunated according to Michałowski et al. (1999) while the protozoa established in the rumen originating from in vitro cultures.

Rumen contents were sampled just before the morning feeding and 4, 8 and $12 \mathrm{~h}$ thereafter. Rumen digesta was evacuated and weighed just before the morning and evening feeding. Samples of reticular fluid were collected every $2 \mathrm{~h}$. The samples for counting protozoa were fixed with $4 \%$ formaldehyde, while the others were kept frozen at $-20^{\circ} \mathrm{C}$. The protozoa were counted using a light microscope. Starch and reserve polysaccharide were determined quantitatively after digestion with amyloglucosidase (Rose et al., 1991). Polyethylene glycol given to the rumen was estimated in the sampled reticular fluid according to Hyden (1961) to calculate the volume of the omasal influent.

Mean values were calculated from the obtained results and compared using Student's t-test.

\section{RESULTS AND DISCUSSION}

The volume of rumen contents varied in relation to the animal and experimental period (Tables 1 and 2). Establishment of the Entodinium caudatum population caused a decrease in the numbers of Eudiplodinium maggii in sheep 35. This decrease resulted perhaps from the competition of both ciliate species for starch (Bełżecki et al., 2004). The number of Eudiplodinium maggii in sheep 33 was three times lower than in sheep 35. Thus, it is possible that the quantity of starch available for these ciliates did not decrease after establishment of Entodinium caudatum. The changes in $\alpha$-D-glucose polymers following the establishment of ciliates in the rumen could result from engulfment of starch grains by ciliates and reduction in the quantity of starch quickly fermented by amylolytic bacteria. It is also suggested that the rumen ciliates degrade and ferment starch much more slowly than bacteria (McAllister and Cheng, 1996). The obtained results are in line with the findings of Mendoza et al. (1993) on the effect of a mixed fauna, but in disagreement with the data of Veira et al. (1983) and Rowe et al. (1985). 
Table 1. The rumeno-reticular characteristics of sheep No. 33 free of ciliates (I) and refaunated with either Eudiplodinium maggii (II) or Eudiplodinium maggii and Entodinium caudatum (III). Mean values $(\mathrm{n}=3)$

\begin{tabular}{|c|c|c|c|}
\hline \multirow{2}{*}{ Characteristics } & \multicolumn{3}{|c|}{ Experimental periods } \\
\hline & $\mathrm{I}$ & II & III \\
\hline Rumen content volume, $\mathrm{kg}$ & $13.5^{\mathrm{a}}$ & $16.8^{\mathrm{ab}}$ & $18.3^{\mathrm{b}}$ \\
\hline Total 1,4;1,6- $\alpha$-D-glucans, g/rumen & $8.1^{\mathrm{a}}$ & $13.8^{\mathrm{a}}$ & $20.6^{\mathrm{b}}$ \\
\hline Eudiplodinium maggii, $\left(\times 10^{3} / \mathrm{g}\right.$ rumen content $)$ & 0.0 & $13.5^{\mathrm{a}}$ & $14.3^{\mathrm{a}}$ \\
\hline Entodinium caudatum $\left(\times 10^{3} / \mathrm{g}\right.$ rumen content $)$ & 0.0 & 0.0 & 181.2 \\
\hline Volume of omasal influent, $1 / 12 \mathrm{~h}$ & $12.4^{\mathrm{a}}$ & $14.0^{\mathrm{a}}$ & $16.1^{\mathrm{a}}$ \\
\hline Total 1,$4 ; 1,6-\alpha$-D-glucans passing to omasum, $g / 12 \mathrm{~h}$ & $5.4^{\mathrm{a}}$ & $10.5^{\mathrm{b}}$ & $15.1^{\mathrm{b}}$ \\
\hline Eudiplodinium maggii ( $10^{3} / \mathrm{ml}$ reticular fluid) & 0.0 & $3.7^{\mathrm{a}}$ & $1.6^{\mathrm{b}}$ \\
\hline Entodinium caudatum $\left(10^{3} / \mathrm{ml}\right.$ reticular fluid) & 0.0 & 0.0 & 98.9 \\
\hline
\end{tabular}

values in a row marked with different letters differ significantly $(\mathrm{P}<0.05)$

The outflow rate from the reticulum was calculated according to Michałowski (1998). Despite selective retention of ciliates in the rumen, the increase in the quantity of $\alpha$-glucose polymers passing to the omasum was observed $(\mathrm{P}<0.05)$. It suggests that the majority of these polymers were not the cellular polysaccharides of protozoa.

Table 2. The rumeno-reticular characteristics of sheep No. 35 free of ciliates (I) and refaunated with either Eudiplodinium maggii (II) or Eudiplodinium maggii and Entodinium caudatum (III).Mean values $(\mathrm{n}=3)$

\begin{tabular}{|c|c|c|c|}
\hline \multirow{2}{*}{ Characteristics } & \multicolumn{3}{|c|}{ Experimental periods } \\
\hline & I & II & III \\
\hline Rumen content volume, $\mathrm{kg}$ & $11.0^{\mathrm{a}}$ & $12.5^{\mathrm{a}}$ & $10.9^{\mathrm{b}}$ \\
\hline Total 1,$4 ; 1,6-\alpha$-D-glucans, g/rumen & $9.2^{\mathrm{a}}$ & $12.0^{\mathrm{a}}$ & $20.8^{\mathrm{a}}$ \\
\hline Eudiplodinium maggii, $\left(\times 10^{3} / \mathrm{g}\right.$ rumen content $)$ & 0.0 & $41.6^{\mathrm{a}}$ & $21.3^{\mathrm{b}}$ \\
\hline Entodinium caudatum $\left(\times 10^{3} / \mathrm{g}\right.$ rumen content $)$ & 0.0 & 0.0 & 253.9 \\
\hline Volume of omasal influent, $1 / 12 \mathrm{~h}$ & $10.9^{\mathrm{a}}$ & $11.1^{\mathrm{a}}$ & $10.0^{\mathrm{a}}$ \\
\hline Total 1,$4 ; 1,6-\alpha-D$-glucans passing to omasum, $g / 12 \mathrm{~h}$ & $5.9^{\mathrm{a}}$ & $14.7^{\mathrm{b}}$ & $17.4^{\mathrm{b}}$ \\
\hline Eudiplodinium maggii $\left(10^{3} / \mathrm{ml}\right.$ reticular fluid) & 0.0 & $9.1^{\mathrm{a}}$ & $4.0^{\mathrm{b}}$ \\
\hline Entodinium caudatum $\left(10^{3} / \mathrm{ml}\right.$ reticular fluid $)$ & 0.0 & 0.0 & 207.7 \\
\hline
\end{tabular}

values in a row marked with different letters differ significantly $(\mathrm{P}<0.05)$

\section{CONCLUSIONS}

The establishment of ciliates diminished starch digestion and fermentation in the rumen and increased the outflow of $\alpha$-glucose polymers to the omasum, which resulted in an improved glucose supply to the host. This improvement arises perhaps mainly from the reduction in the bacterial degradation of starch in the rumen. 


\section{REFERENCES}

Bełżecki G., Miltko R., Michałowski T., 2004. Why does the establishment of starch preferring Entodinium caudatum in the rumen decrease the numbers of the fibrolytic ciliate Eudiplodinium maggii. Folia Microbiol. 49, 139-142

Hyden S., 1961. The use of reference substance and the measurement of flow in the alimentary tract. In: O. Lewis (Editor). Digestive Physiology and Nutrition of the Ruminants. Butterworths, London, pp. 35-47

Lyle R.R., Johnson R.R., Backus W.R., 1981. Ruminal characteristic as affected by monensin, type of protein supplement and proportions of whole wheat and corn in forage-free diet to the finishing steers. J. Anim. Sci. 53, 1377-1383

McAllister T.A., Cheng K.-J., 1996. Microbial strategies in the ruminal digestion of cereal grains. Anim. Feed Sci. Tech. 62, 29-36

Mendoza G.D., Birtton R.A., Stock R.A., 1993. Influence of ruminal protozoa on size and extent of starch digestion and ruminal fermentation. J. Anim. Sci. 71, 1572-1578

Michałowski T., 1998. A proposed simple method for determining the outflow of ciliates from the reticulo-rumen. J. Anim. Feed Sci. 7, 83-92

Michałowski T., Harmeyer J., Bełżecki G., 1999. The importance of washing the omasum for successful defaunation of sheep. J. Anim. Feed. Sci. 8, 611-619

Rose R., Rose C.L., Omi S.K., Forry K.R., Durall D.M., Bigg W.L., 1991. Starch determination by perchloric acids vs enzymes: Evaluating the accuracy and precision of six colorimetric methods. J. Agr. Food Chem. 39, 2-11

Rowe J.B., Davies A., Broom A.W.J., 1985. Quantitative effect of defaunation on rumen fermentation and digestion in sheep. Brit. J. Nutr. 54, 105-119

Veira D.M., Ivan M., Jui P.Y., 1983. Rumen ciliate protozoa: Effect on digestion in the stomach of sheep. J. Dairy Sci. 66, 1015-1022

Whitelaw F.G., Eadie J.M., Mann S.O., Reid R.S., 1972. Some effects of rumen ciliate protozoa in cattle given restricted amounts of a barley diet. Brit. J. Nutr. 27, 425-437

Williams A.G., Coleman G.S., 1992. The Rumen Protozoa. Springer-Verlag, New York

\section{STRESZCZENIE}

\section{Wpływ selektywnie dobranej fauny żwaczowej na trawinie skrobi i odpływ polimerów $\alpha$-glukozy z czepco-żwacza owiec}

Rola orzęsków w trawieniu i przemianach skrobi w żwaczu jest słabo poznana. Celem niniejszych badań było zbadanie wpływu orzęsków Eudiplodinium maggii i Entodinium caudatum na przemianę skrobi paszowej w żwaczu. Stwierdzono, że po ustaleniu się populacji pierwotniaków nastąpił wzrost zwartości polimerów $\alpha$-D-glukozy w żwaczu oraz ich odpływ do ksiąg $(\mathrm{P}<0,05)$. Stwierdzono istnienie konkurencji między gatunkami wszczepionymi do żwacza o skrobię. W podsumowaniu zasugerowano, że wpływ pierwotniaków na przemianę skrobi polegał na hamowaniu bakteryjnej fermentacji tego węglowodanu w żwaczu. 